\title{
APPLICATION PROGRAMMING INTERFACES PADA APLIKASI GEO SOCIAL COMMERCE
}

\author{
${ }^{1}$ Ainu Faisal Pambudy, ${ }^{2}$ Soni Fajar Surya Gumilang, ${ }^{3}$ Muhammad Azani Hasibuan \\ ${ }^{1,2,3}$ Sistem Informasi, Fakultas Rekayasa Industri, Universitas Telkom \\ ${ }^{1}$ ainu.faisal@gmail.com, ${ }^{2}$ sonifajar@gmail.com, ${ }^{3}$ muhammad.azani@gmail.com
}

\begin{abstract}
Abstrak-Dengan maraknya dunia digital dan internet kebanyakan dari kita mencari barang atau jasa di internet, walaupun sebenarnya hal yang kita cari tersebut ada disekitar kita. Kami telah melakukan survey kepada 395 koresponden, $71 \%$ orang pernah mengalami kesulitan mencari barang atau jasa yang dibutuhkan. Disisi lain $62 \%$ penjual mengaku pernah kesulitan mempromosikan produk atau jasa mereka. Dari questioner tersebut juga didapatkan beberapa masalah yang dialami penjual dan pembeli. Marketspot merupakan sebuah solusi Geo Social Commerce yang eklusif di mobile phone untuk membantu penjual bertemu dengan customer disekelilingnya dengan menampilkan customer yang membutuhkan di sebuah peta, dapat langsung berinteraksi dan begitu sebaliknya. Dalam solusi ini kami menggabungkan unsur social dan e-commerce yang berbasis GIS. Produk dalam penelitian ini adalah API dan versi website. API dan web dibuat berbasis PHP dengan framework Laravel 5. REST API yang dibuat disini menghasilkan data dalam bentuk JSON. Dalam proses pengembangannya API ini dikerjakan dengan metode iterative dan incremental.
\end{abstract}

Kata kunci: marketspot, API, social commerce, GIS, jual beli, iterative dan incremental

\section{PENDAhUluan}

Sekarang ini kita sering mengalami kesulitan untuk mendapatkan suatu barang atau jasa disekitar kita. Dengan maraknya dunia digital dan internet kebanyakan dari kita mencari barang atau jasa di internet, walaupun sebenarnya hal yang kita cari tersebut ada disekitar kita. Berdasarkan survey kepada 395 koresponden, diperoleh hasil seperti Gambar 1 dan Gambar 2. Berdasarkan gambar tersebut, $71 \%$ orang pernah mengalami kesulitan mencari barang atau jasa yang dibutuhkan. Disisi lain, $62 \%$ penjual mengaku pernah kesulitan mempromosikan produk atau jasa mereka. Dari kuesioner tersebut juga didapatkan beberapa masalah yang dialami, baik dari sisi pembeli maupun pejual. Dari masalah masalah tersebut dibutuhkan sebuah solusi yang tepat.

Dari masalah diatas kami berinovasi dengan membuat sebuah media marketplace dengan pengalaman baru dan dapat menyelesaikan masalah-masalah tersebut. Solusi yang kami tawarkan adalah Marketspot. Marketspot merupakan sebuah Geo Social Commerce yang eklusif di mobile phone untuk membantu penjual bertemu dengan customer disekelilingnya dengan menampilkan customer yang membutuhkan di sebuah peta, dapat langsung berinteraksi dan begitu sebaliknya. Dalam solusi ini kami menggabungkan unsur social dan e-commerce yang berbasis GIS dengan berbagai pertimbangan.
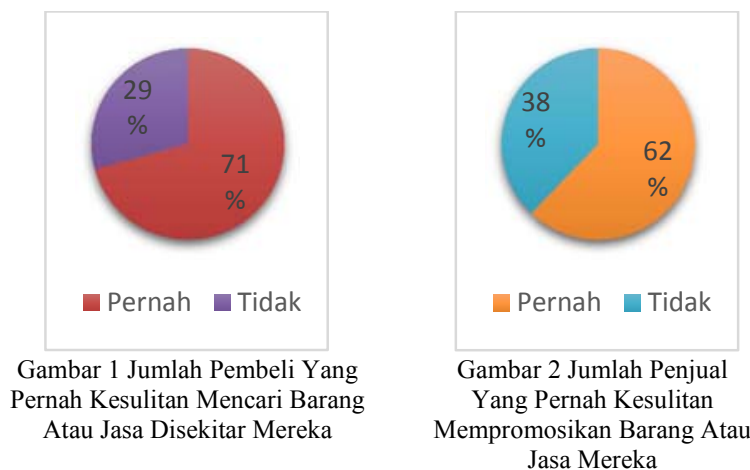

Menurut beberapa data mulai dari pengguna internet, social media, ecommerce dan smartphone merupakan mangsa pasar yang sangat besar, sehingga bisa kita kombinasikan antara keempat komponen diatas menjadi satu solusi yang efektif dan solusi tersebut adalah sebuah aplikasi social commerce pada smartphone.

Social commerce saja belum cukup karena banyak koresponden yang menyatakan kesulitan dalam mencari lokasi penjual maka kami memberikan berbasis GIS. Dengan menggunakan GIS, kita bisa memetakan penjual beserta semua informasi-informasi terkait dengan lokasinya sehingga diharapkan para pembeli bisa menemukan barang atau jasa disekitar mereka dengan mudah. Dan ternyata ide ini mendapatkan respon yang positif. Berdasarkan hasil survey dapat dilihat di Gambar 3 dan Gambar 4, sekitar $85 \%$ pembeli dan $90 \%$ penjual merasa terbantu apabila dibuat solusi seperti ini.

Dalam men-develop sebuah produk di smartphone harus di sesuaikan dengan keadaan pengguna, menurut data dari International Data Corporation (IDC) Worldwide Quarterly Mobile Phone Tracker menyebutkan bahwa pengguna smartphone di dunia sangatlah beragam mulai dari yang yang tertinggi Android, IOS, Windows Phone, diikuti Blackberry OS dan OS lainnya. Dari data diatas terlihat pengguna Android sangatlah tinggi dengan perkembangan yang cukup stabil, ini lah yang melatar belakangi kami untuk mendevelop solusi dalam Android. 


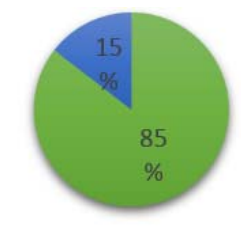

- Membantu

Gambar 3 Jumlah Pembeli Yang Merasa Terbantu Dengan Adanya Aplikasi Social Commerce Berbasis GIS di Smartphone

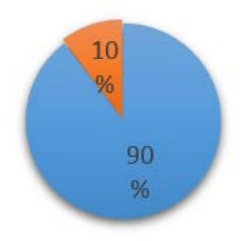

- Membantu

- Tidak Membantu

Gambar 4 Jumlah Penjual Yang Merasa Terbantu Dengan Adanya Aplikasi Social Commerce Berbasis GIS di Smartphone

Meskipun teknologi komputer modern dan teknologi database telah berkembang pesat, tapi untuk mendevelop multiplatform juga masih dibutuhkan teknik developmen yang berbeda-beda sehingga ancaman akan keamanan datapun semakin tinggi. Dari masalah diatas dibutuhkan sebuah media untuk menyamakan teknik development dan memfokuskan keamanan data dari satu sisi, maka dibutuhkan sebuah API (Application Programming Interface) untuk membantu development dan menstandartkan sistem.

Dalam trend industri yang baru dan awal mula dibukanya APIs dilatarbelakangi oleh pengembangan teknologi dan kemajuan pasar seperti : 1.) Distributed System, untuk menyediakan layanan yang efisien, meningkatkan reliability dan avaibility, dan kelebihan lain untuk integrasis sistem; 2.) Teknologi perangkat lunak, seperti pemrograman berbasis objek untuk menyediakan layanan terfokus pada bagian bagian yang penting, penyembunyian data, dan abtraksi untuk mengingkatkan software extensibility dan penggunaan kembali; 3.) Jaringan yang terbagi, yang dapat digantikan pada pemrosessan yang terpusat melalui jaringan; 4.) Komponen Teknologi perangkat keras dan perangkat lunak untuk meningkatkan reliability dan stamina untuk beberapa point dimana dapat meningkatkan penggabungan jaringan komunikasi yang menunjang aplikasi high-reliability [1].

\section{SOCIAL MEDIA DAN SOCIAL COMMERCE}

Social Media adalah situs atau layanan online yang sebagai bagian integral dari fungsinya memungkinkan dan mendorong adanya interaksi sosial seperti komentar, voting, diskusi, dan berbagi. Sosial media meghapus batasan-batasan manusia untuk bersosialisasi, batasan ruang maupun waktu, dengan media sosial ini manusia dimungkinkan untuk berkomunikasi satu sama lain dimanapun mereka bereda dan kapanpun, tidak peduli seberapa jauh jarak mereka, dan ttidak peduli siang atau pun malam. [2]

Social commerce adalah gabungan dari berbelanja dengan media sosial, karena itu kita bisa mengkategorikannya berdasarkan perilaku berbelanja, penjualan dan rekomendasi seseorang seperti dibawah ini [3].Ada beberapa jenis Social Commerce, antara lain: 1) Social network driven sales, Penjualan dilakukan dan berpusat di situs media sosial seperti Facebook atau Twitter. 2) Peer to peer sales platforms, Penjualan seperti ini menawarkan tempat dimana pengguna bisa berkomunikasi dan menjual produk secara langsung dengan pengguna lain. 3) Peer recommendations, Pengguna bisa melihat rekomendasi pengguna lain. 4) Group buying, Pengguna bisa membeli barang dan jasa pada harga yang lebih murah ketika cukup banyak pengguna lain setuju untuk melakukan pembelian akan barang atau jasa tersebut. 5) User curated shopping, Para pengguna membuat dan membagikan daftar barang atau jasa yang bisa dibeli oleh oleh pengguna lain. 6) Participatory commerce, Pengguna bisa masuk dalam proses produksi. 7) Social shopping, Situs menyediakan sesi obrolan untuk para pengguna sehingga mereka bisa berkomunikasi dengan teman mereka atau pengguna lain untuk mendapatkan saran.

\section{Metodologi}

Model konseptual merupakan konsep pemikiran yang dapat membantu peneliti untuk merumuskan pemecahan masalah dan membantu dalam merumuskan solusi dari permasalahan yang ada. Pada penelitian ini akan dihasilkan sebuah API dan aplikasi social commerce berbasis GIS yang diberi nama Marketspot. Model konseptual dari penelitian ini bisa dilihat di Gambar 5.

Metodologi pengembangan sistem yang dipakai untuk membangun Marketspot adalah metode iterative \& incremental. Urutan iterasi dari penelitian ini bisa dilihat di Gambar 6.

Penelitian dilakukan dengan menggunakan metode iterative dan incremental yang terdiri dari empat fase, yaitu inception, elaboration, construction, dan transition. Detail tahapan bisa dilihat di Tabel I. Penjelasan dari tiap fase pemecahan masalah adalah sebagai berikut.

\section{Tahap Pendahuluan}

Pada tahap ini dilakukan penetapan latar belakang, perumusan masalah, pembatasan masalah, penetapan tujuan dan studi literatur. Penetapan latar belakang dilakukan berdasarkan kondisi eksisting di masyarakat dalam proses jual beli barang atau jasa yang kemudian dipadukan dengan perkembangan sistem operasi Android sehingga perlu dibuat sebuah aplikasi social commerce berbasis GIS di Android selain itu juga dipadukan dengan kebutuhan pasar akan data perilaku pelanggan disuatu wilayah. Perumusan masalah didasari oleh latar belakang 
yang sudah diuraikan sebelumnya. Selain itu, perlu dilakukan pembatasan masalah agar pemecahan masalah dapat dilakukan dengan lebih terarah. Kemudian dilakukan penetapan tujuan setelah merumuskan masalah. Dan dilakukan juga studi literatur untuk menggali teori-teori dasar yang digunakan sebagai landasan dalam melakukan penelitian.

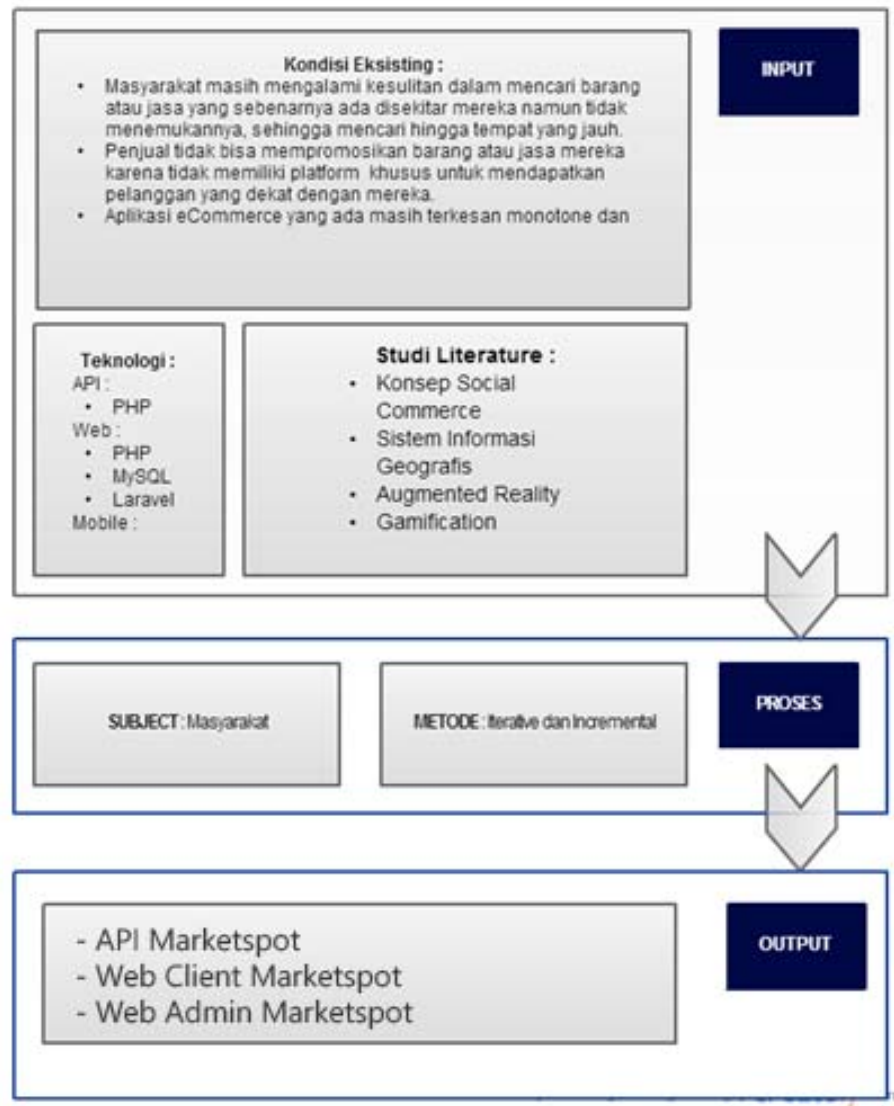

Gambar 5 Model Konseptual

Fase Inception

Fase inception merupakan tahapan pertama dari metode pengembangan sistem iterative dan incremental. Pada fase ini dilakukan proses iterasi pertama yaitu pemodelan bisnis kondisi eksisiting, penentuan kebutuhan aplikasi dan analisis. Pemodelan bisnis kondisi eksisting bertujuan untuk mengetahui bagaimana proses jual beli yang dilakukan masyarakat. Analisis yang dilakukan adalah analisis kebutuhan aplikasi. Analisis kebutuhan aplikasi bertujuan untuk mengetahui siapa saja pengguna aplikasi dan apa saja yang bisa dilakukan oleh aplikasi.

\section{Fase Elaboration}

Fase elaboration merupakan fase kedua dari metode pengembangan sistem iterative dan incremental. Pada fase ini dilakukan proses iterasi kedua yaitu pemodelan bisnis usulan, penentuan kebutuhan aplikasi, analisis, desain, implementasi dan pengujian.

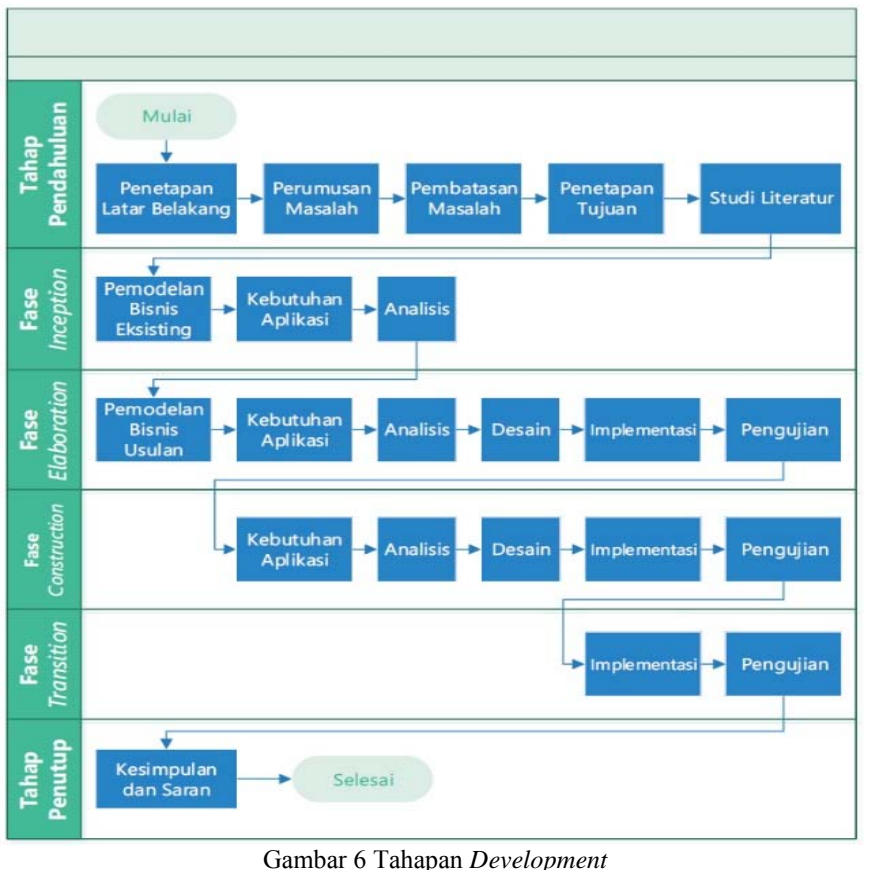

Gambar 6 Tahapan Development

TABEL I

DETAIL TARGET SETIAP ITERASI

\begin{tabular}{|c|c|c|}
\hline Tahapan & Iterasi & Target \\
\hline Inception & Initial & $\begin{array}{l}\text { Perencanaan } \\
\text { Pendefinisian } \\
\text { Aplikasi } \\
\text { Fitur } \\
\text { Lingkup }\end{array}$ \\
\hline \multirow[t]{2}{*}{ Elaboration } & Elab \#1 & \multirow{2}{*}{$\begin{array}{l}\text { ERD } \\
\text { Wireframe } \\
\text { Class Diagram } \\
\text { Sequence Diagram }\end{array}$} \\
\hline & Elab \#2 & \\
\hline \multirow[t]{4}{*}{ Construction } & $\begin{array}{l}\text { Const \#1 } \\
\text { (release 1) }\end{array}$ & \multirow{4}{*}{$\begin{array}{l}\text { API } \\
\text { Mobile Apps } \\
\text { Web Client } \\
\text { Web Admin }\end{array}$} \\
\hline & $\begin{array}{l}\text { Const \#2 } \\
\text { (release 2) }\end{array}$ & \\
\hline & $\begin{array}{l}\text { Const \#3 } \\
\text { (release 3) }\end{array}$ & \\
\hline & $\begin{array}{l}\text { Const \#4 } \\
\text { (release 4) }\end{array}$ & \\
\hline Transition & $\begin{array}{l}\text { Tran \#1 } \\
\text { (release final) }\end{array}$ & $\begin{array}{l}\text { Deployment Diagram } \\
\text { Deploy Aplikasi }\end{array}$ \\
\hline Tahap Penutup & Sidang & Laporan Akhir \\
\hline
\end{tabular}

Pemodelan bisnis kondisi usulan bertujuan untuk memberikan rancangan guna memperbaiki proses bisnis eksisting. Analisis yang dilakukan adalah analisis kebutuhan aplikasi, analisis arsitektur data, analisis arsitektur aplikasi dan analisis arsitektur teknologi. Analisis kebutuhan aplikasi yang dilakukan pada tahap ini merupakan perbaikan dan penambahan pada fase sebelumnya. Analisis arsitektur data bertujuan untuk mengetahui dan mengidentifikasi bagaimana struktur data 
yang akan digunakan oleh aplikasi. Analisis arsitektur aplikasi bertujuan untuk mengetahui dan mengidentifikasi obyek dan struktur fungsi pada sistem yang akan dibangun. Dan analisis arsitektur teknologi bertujuan untuk menentukan teknologi apa saja yang bisa digunakan untuk mewujudkan aplikasi.

Setelah analisis dilakukan, selanjutnya dilakukan proses desain. Desain yang dilakukan adalah desain kebutuhan aplikasi, desain arsitektur data, desain arsitektur aplikasi dan desain arsitektur teknologi. Desain kebutuhan sistem dipresentasikan melalui use case diagram, wireframe dan sequence diagram. Desain arsitektur data dipresentasikan dengan Entity Relationship Diagram (ERD). Desain arsitektur aplikasi dipresentasikan melalui class diagram, package diagram dan component diagram. Desain arsitektur teknologi dipresentasikan melalui deployment diagram. Setelah tahap analisis dan desain dilakukan, selanjutnya dilakukan proses implementasi. Proses implemenasi pada fase elaboration merupakan pembangunan kode program. Selanjutnya hasil implementasi langsung di uji coba.

\section{Fase Contruction}

Fase construction merupakan fase ketiga dari metode pengembangan sistem iterative dan incremental. Pada fase ini dilakukan proses iterasi ketiga yaitu desain, implementasi dan pengujian.

Proses desain dilakukan dengan melanjutkan dan memperbaiki desain dari hasil fase elaboration. Setelah desain tahap lanjut dilakukan, selanjutnya dilakukan proses implementasi. Proses implemenasi pada fase construction merupakan lanjutan pembangunan kode program dari proses coding tahap elaboration. Selanjutnya hasil implementasi langsung di uji coba.

\section{Fase Transition}

Fase transition merupakan fase keempat dari metode pengembangan sistem iterative dan incremental. Pada fase ini, sistem sudah memasuki proses finishing dan setelah itu akan langsung dilakukan uji coba.

\section{Tahap Penutup}

Pada tahap penutup, dilakukan proses penarikan kesimpulan dan saran dari penelitian yang dilakukan.

\section{HASIL ANALISIS DAN DESAIN}

\section{Kebutuhan Bisnis}

Marketspot disini dibuat karena adanya masalahmasalah yang dialami oleh penjual dan pembeli. Banyak penjual mengaku kesulitan dalam mempromosikan barang atau jasanya, baik karena ketidakefektifan promosi maupun karena mahalnya biaya yang diperlukan untuk membuat promosi. Pembeli juga sering merasa kesulitan, mereka sering tidak menemukan suatu barang atau jasa sehingga mereka terpaksa harus membeli barang tersebut di tokotoko online. Namun sayangnya, seringkali biaya pengiriman barang jauh lebih besar daripada harga barang yang mereka beli. Selain biaya pengiriman yang besar, pembeli online juga dihadapi dengan masalah penipuan. Banyak penjual-penjual fiktif yang menawarkan barang dengan harga murah sehingga banyak pembeli tertipu. Masalah-masalah inilah yang ingin diselesaikan pada penelitian ini.

Aplikasi ini nantinya berfungsi sebagai media sosial sehingga pembeli dan penjual bisa saling berinteraksi satu sama lain. Selain itu aplikasi ini juga memerlukan sebuah fitur untuk membantu pembeli mengidentifikasi mana penjual fiktif dan mana penjual yang memang memiliki pelayanan yang baik. Dan tidak kalah pentingnya adalah fitur untuk mengetahui dimana lokasi penjual atau pembeli. Fitur-fitur ini digabung menjadi satu sehingga aplikasi ini bisa bersaing dengan aplikasi-aplikasi besar lainnya yang memiliki fitur serupa.

\section{Kebutuhan Fungsional}

1. Spesifikasi Pengguna

Target pengguna dalam aplikasi ini adalah penjual dan pembeli. Aplikasi ini tidak membedakan penjual dan pembeli, seorang pengguna nantinya akan bisa bertindak sebagai penjual maupun pembeli. Pengguna diharapkan memiliki kemampuan dasar dalam mengoperasikan aplikasi-aplikasi Android.

Pada Application Programming Interfaces (API) hasilnya ditujuan untuk di pakai dalam pembuatan mobile apps. Pengguna utama dari API ini ialah developer mobile apps yang memiliki kemampuan pemrograman mobile apps dan pengentahuan tentang penggunaan API.

Pada versi web ada tiga bagian. Pertama, website single view yang di akses oleh publik baik user yang terdaftar ataupun yang belum terdaftar. Pengguna web single view ini diharap memiliki kemampuan dalam pemakaian internet. Yang kedua ialah website client yang diakses oleh pengguna yang telah terdaftar. Disini pengguna bisa sebagai penjual ataupun pembeli. Pengguna diharapkan memiliki kemampuan dasar internet. Pada bagian ini pengguna juga dapat membuat iklan dan dapat melihat laporan behavior user marketspot, baik untuk kepentingan marketing atau kepentingan lain. Pengguna client juga diharap memiliki kemampuan dalam membaca dan memanfaatkan informasi. Yang terakhir yaitu website admin yang diperuntukkan pihak internal untuk memanage data user ataupun data post yang ada di marketspot. Pengguna web admin diharap memiliki kemampuan dalam penggunaan internet, dan mengerti Standard Operating Procedures (SOP) dari marketspot.

\section{Diagram Unified Modelling Language}

Berikut ada beberapa use case untuk menggambarkan fungsionalitas dari produk yang akan dikerjakan. Yang pertama adalah use case untuk menggambarkan fungsional dari API (Gambar 2). Selanjutnya adalah use case untuk menggambarkan web client yang dapat dilihat di Gambar 3. Dan yang terakhir adalah fungsionalitas dari web admin yang dapat dilihat di Gambar 4. 


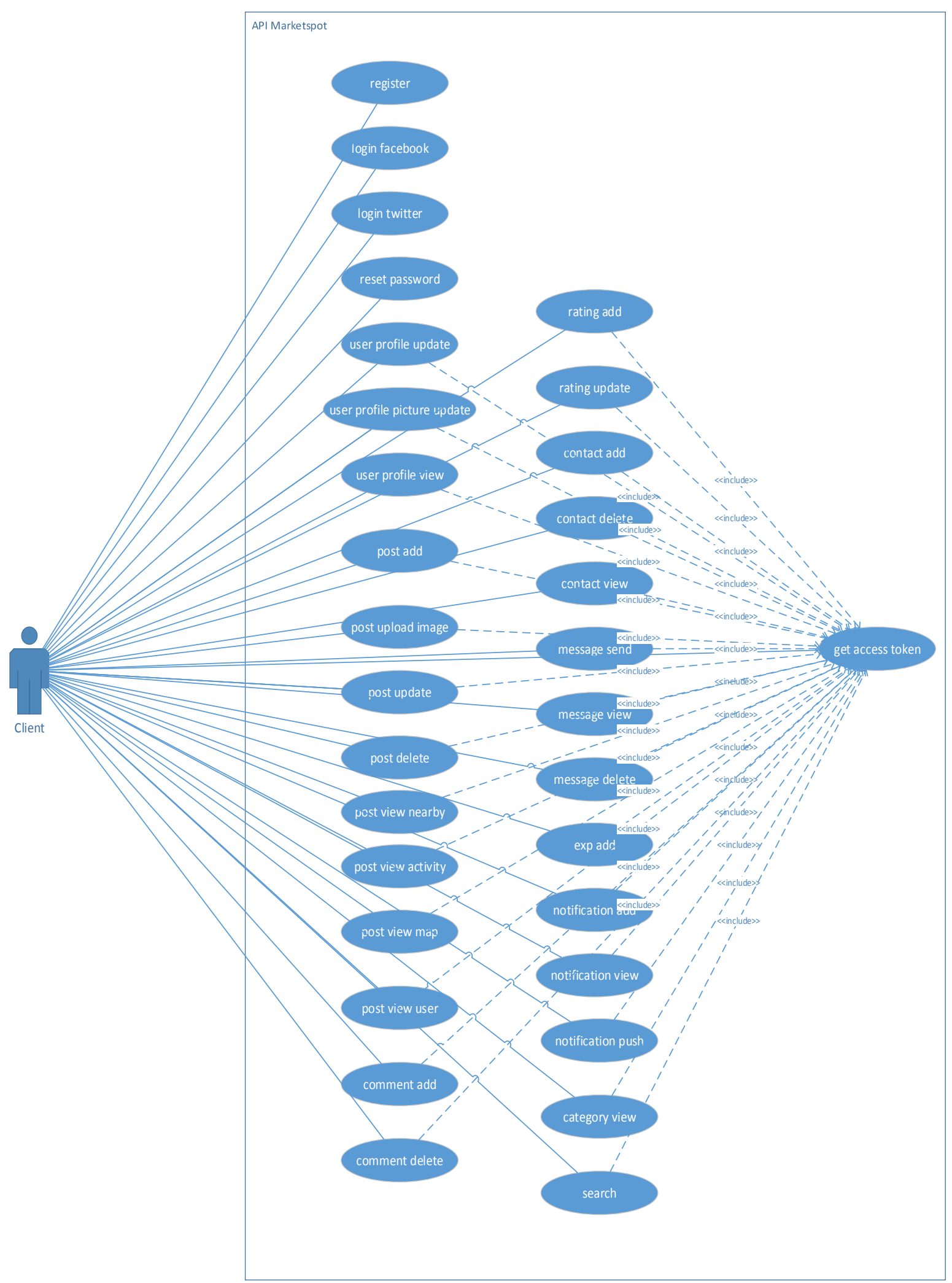

Gambar 2 Use Case API 


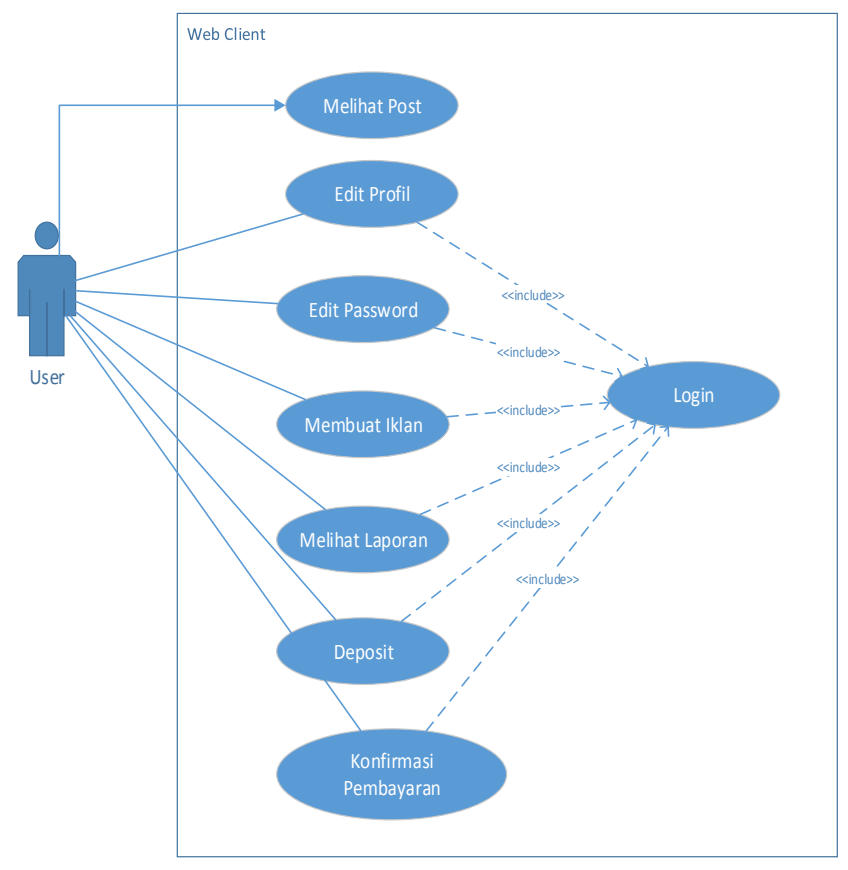

Gambar 3 Use Case Web Client

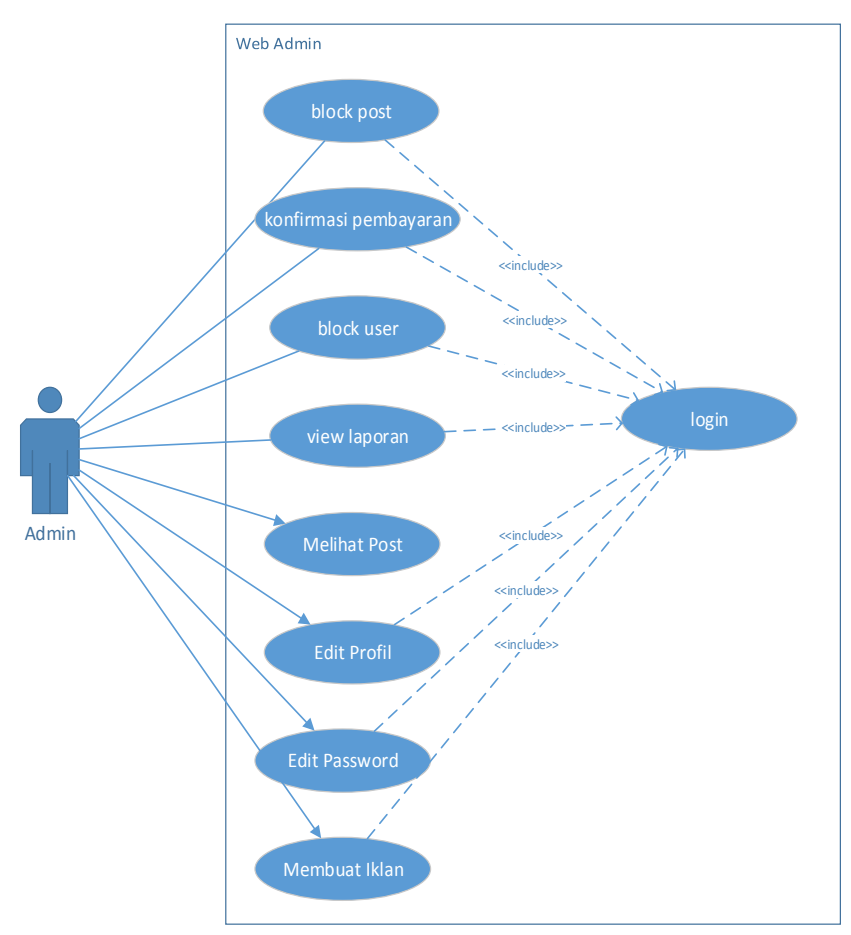

Gambar 4 Use Case Admin

\section{Teknologi}

Sebagai framework utama yang dipakai untuk mengembangkan api dan versi website adalah Laravel 5. Laravel adalah framework MVC web-pengembangan yang ditulis dalam PHP. Ini telah dirancang untuk meningkatkan kualitas perangkat lunak Anda dengan mengurangi baik biaya pengembangan awal dan biaya pemeliharaan, dan untuk meningkatkan pengalaman bekerja dengan aplikasi Anda dengan menyediakan sintaks ekspresif yang jelas dan inti set fungsi yang akan menghemat jam waktu pelaksanaan.

Selain Laravel untuk membantu dalam meningkatkan performance dalam pencarian dan management post juga menggunakan Elasticsearch. ElasticSearch merupakan search engine full-text yang bisa diakses melalui RESTful API. Search engine ini berorientasi dokumen (hampir seperti MongoDB) artinya engine ini akan menyimpan objek atau dokumen daripada menyimpan data dengan representasi baris dan kolom. Dokumen yang disimpan tersebut akan di serialisasi sebagai JSON ketika diakses. ElasticSearch juga sangat membantu terutama untuk pencarian data besar dengan banyak parameter dan penggunaan data geografis.

\section{Entity Relationship Diagram}

Tahap selanjutnya adalah pembuatan Entity Relationship Diagram (ERD) yang digunakan dalam pengerjaan.

\section{Hasil API}

Berikut merupakan data API yang telah dibuat dalam penelitian ini, bisa dilihat di Tabel II.

\begin{tabular}{|c|c|c|}
\hline \multicolumn{3}{|r|}{$\begin{array}{l}\text { TABEL II } \\
\text { LIST API }\end{array}$} \\
\hline No & API & Deskripsi \\
\hline 1 & $\operatorname{login}$ & $\begin{array}{l}\text { Menangani login user dan generate } \\
\text { access token }\end{array}$ \\
\hline 2 & register & Untuk pendaftaran pengguna baru \\
\hline 3 & $\begin{array}{l}\text { user profile } \\
\text { update }\end{array}$ & mengubah data profile pengguna \\
\hline 4 & $\begin{array}{l}\text { user profile } \\
\text { picture update }\end{array}$ & Mengubah foto profil pengguna \\
\hline 5 & user profile view & Menampilkan profil pengguna \\
\hline 6 & login facebook & $\begin{array}{l}\text { Pengguna bisa login menggunakan } \\
\text { facebook }\end{array}$ \\
\hline 7 & $\begin{array}{l}\text { login Gambar } 5 \\
\text { ERD Marketspot } \\
\text { twitter }\end{array}$ & $\begin{array}{l}\text { Pengguna bisa login menggunakan } \\
\text { twitter }\end{array}$ \\
\hline 8 & reset password & Pegguna bisa mereset password \\
\hline 9 & post add & $\begin{array}{l}\text { Untuk menampah post baru baik } \\
\text { itu need ataupun offer }\end{array}$ \\
\hline 10 & $\begin{array}{l}\text { post upload } \\
\text { image }\end{array}$ & $\begin{array}{l}\text { Untuk mengupload gambar ke } \\
\text { dalam post }\end{array}$ \\
\hline 11 & post update & Untuk mengubah data post \\
\hline 12 & post delete & $\begin{array}{l}\text { Untuk menghapus post yang telah } \\
\text { dibuat pengguna }\end{array}$ \\
\hline 13 & post view nearby & $\begin{array}{l}\text { Untuk menampilkan semua post } \\
\text { yang ada didekat area pengguna }\end{array}$ \\
\hline 14 & post view activity & $\begin{array}{l}\text { Untuk menampilkan semua post } \\
\text { yang dibuat oleh pengguna yang } \\
\text { telah masuk daftar kontak }\end{array}$ \\
\hline 15 & post view map & Untuk menampilkan semua post \\
\hline
\end{tabular}




\begin{tabular}{|l|l|l|}
\hline & & $\begin{array}{l}\text { yang ada dalam cakupan peta yang } \\
\text { tampil di layar }\end{array}$ \\
\hline $\mathbf{1 6}$ & post view user & $\begin{array}{l}\text { Untuk menampilkan semua post } \\
\text { yang telah dibuat oleh pengguna }\end{array}$ \\
\hline $\mathbf{1 7}$ & comment add & $\begin{array}{l}\text { Untuk menambahkan komentar } \\
\text { dalam post }\end{array}$ \\
\hline $\mathbf{1 8}$ & comment delete & $\begin{array}{l}\text { Untuk menghapus komentar yang } \\
\text { telah dibuat }\end{array}$ \\
\hline $\mathbf{1 9}$ & rating add & $\begin{array}{l}\text { Untuk memberi rating pada sebuah } \\
\text { post }\end{array}$ \\
\hline $\mathbf{2 0}$ & rating update & $\begin{array}{l}\text { Untuk mengubah rating yang telah } \\
\text { diberikan pada sebuah post }\end{array}$ \\
\hline $\mathbf{2 1}$ & contact add & $\begin{array}{l}\text { Untuk menambahkan pengguna } \\
\text { lain dalam kontak }\end{array}$ \\
\hline $\mathbf{2 2}$ & contact delete & $\begin{array}{l}\text { Untuk menghapus pengguna lain } \\
\text { dari dalam kontak }\end{array}$ \\
\hline $\mathbf{2 3}$ & contact view & $\begin{array}{l}\text { Untuk menampilkan semua data } \\
\text { pengguna lain yang ada dalam } \\
\text { kontak }\end{array}$ \\
\hline $\mathbf{2 4}$ & message send & $\begin{array}{l}\text { Untuk mengirimkan pesan antar } \\
\text { pengguna }\end{array}$ \\
\hline $\mathbf{2 5}$ & message view & $\begin{array}{l}\text { Untuk menampilkan data } \\
\text { percakapan pengguna }\end{array}$ \\
\hline $\mathbf{2 6}$ & message delete & $\begin{array}{l}\text { Untuk menghapus data percakapan } \\
\text { pengguna }\end{array}$ \\
\hline $\mathbf{2 7}$ & exp add & $\begin{array}{l}\text { Untuk menambahkan experience } \\
\text { pengguna }\end{array}$ \\
\hline $\mathbf{2 8}$ & notification add & $\begin{array}{l}\text { Untuk pos } \\
\text { pemberitahuan }\end{array}$ \\
\hline $\mathbf{2 9}$ & notification view & $\begin{array}{l}\text { Untuk } \\
\text { pemberitahuan }\end{array}$ \\
\hline $\mathbf{3 1}$ & notification push & $\begin{array}{l}\text { Untuk membuat push notification } \\
\text { pada mobile phone }\end{array}$ \\
\hline category view & $\begin{array}{l}\text { Untuk menampilkan semua data } \\
\text { kategori }\end{array}$ \\
search & $\begin{array}{l}\text { Untuk menampilkan } \\
\text { berdasarkan pencarian kata kunci } \\
\text { dan lokasi. }\end{array}$ \\
\hline
\end{tabular}

4. Hasil Aplikasi

Berikut merupakan hasil tampilan dari fungsionalitas aplikasi Marketspot versi website yang telah dibangun. Hanya beberapa fungsi saja yang ditampilkan. Dalam halaman landing page sebagai halaman pertama marketspot menampilkan keterangan umum tentang marketspot dan pengguna umum bisa selalu mendapatkan update dari marketspot dengan cara melakukan subscribe. Seperti yang ada di Gambar 5.

Selanjutnya adalah halaman login, dimana user bisa mengisikan email dan password untuk masuk kedalam user area, tampilan seperti Gambar 6. Gambar 7 adalah Account management, disini user bisa melakukan update data diri dan mengganti password.

Di halaman Balance ini pengguna dapat melakukan request deposit untuk menambah saldo user. Disana ada berbagai paket deposit yang ditawarkan seperti contoh yang ada di Gambar 8.

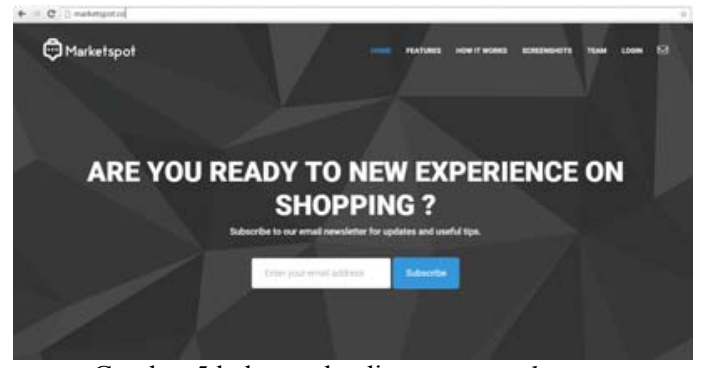

Gambar 5 halaman landing page marketspot

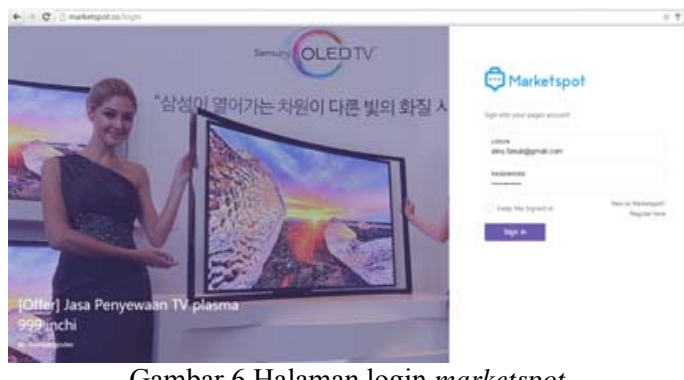

Gambar 6 Halaman login marketspot

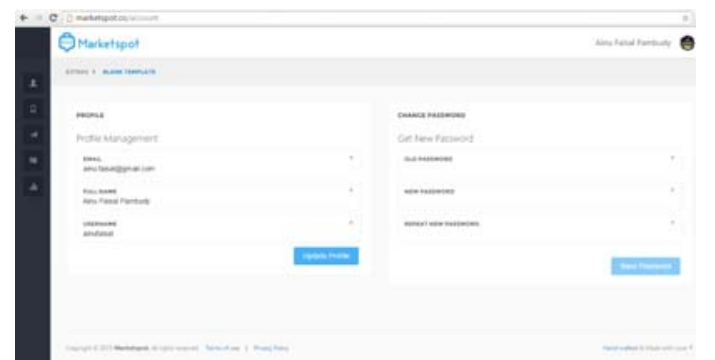

Gambar 7 Halaman Update Profile dan Ganti Password

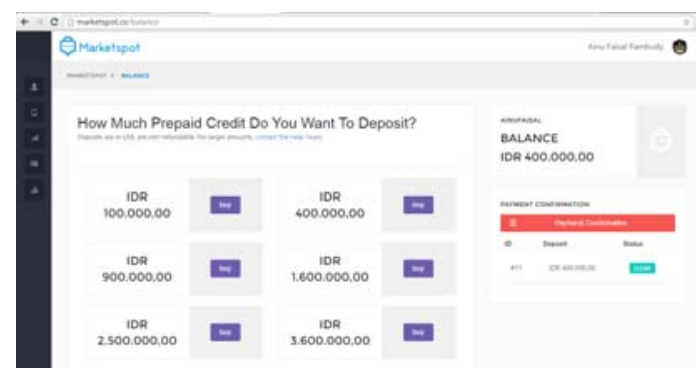

Gambar 8 Halaman Deposit saldo

\section{Pengujian}

Pengujian merupakan tahap yang dilakukan setelah aplikasi selesai. Pengujian bertujuan untuk mengetahui apakah fungsionalitas aplikasi berjalan dengan baik dan mengukur kinerja Marketspot. Pengujian dilakukan pada VPS yang memiliki spesifikasi processor 1 Core, hardisk drive 20 Gb SSD, OS: Ubuntu Server 15.04 x64 dan memory 512MB. Sedangkan untuk web server memakai nginx dan database server menggunakan Mysql. 


\section{A. Pengujian Fungsional}

Dalam pengujian fungsional dilakukan untuk memastikan fungsi-fungsi aplikasi yang dijelaskan di use case berjalan seperti harapan. Hasil dari pengujian didapatkan semua fungsi yang ada telah berjalan sesuai harapan. Sehingga tidak ada masalah.

\section{B. Pengujian Kinerja Aplikasi}

Pengujian ini bertujuan untuk mengetahui availability, kinerja dan kondisi server pada lingkungan yang berbeda. Untuk pengujuan disini menggunakan bantuan aplikasi lain yaitu loader.io yang dilakukan tes dengan urutan mulai dari 10 user, 20 user, 30 user hingga $n$ user perdetik masing-masing selama 1 menit. Pertambahan user dilakukan terus hingga web mengalami error.

Pengujian dilakukan dalam 2 bagian, yaitu bagian API dan Website. Yang pertama dites adalah untuk tes API, dari tes didapatkan hasil seperti pada Tabel III.

TABEL III

HASIL PENGUJIAN API

\begin{tabular}{|l|l|l|l|}
\hline User & Request (req/s) & Time (ms) & Error (\%) \\
\hline 10 & 600 & 596 & 0 \\
\hline 20 & 1200 & 582 & 0 \\
\hline 30 & 1800 & 1559 & 0 \\
\hline & 2400 & 2618 & 0 \\
\hline 50 & 3000 & 3610 & 0 \\
\hline 60 & 3600 & 4845 & 0 \\
\hline 70 & 4200 & 4492 & 0.3 \\
\hline 80 & 4800 & 3067 & 44.5 \\
\hline 90 & 5400 & 1263 & 55.9 \\
\hline 100 & 6000 & 990 & 55.9 \\
\hline
\end{tabular}

TABEL IV

HASIL PENGUJIAN WEBSITE

\begin{tabular}{|l|l|l|l|}
\hline User & Request (req/s) & Time (ms) & Error (\%) \\
\hline 10 & 600 & 836 & 0 \\
\hline 20 & 1200 & 816 & 0 \\
\hline 30 & 1800 & 884 & 0 \\
\hline 40 & 2400 & 1615 & 0 \\
\hline 50 & 3000 & 2411 & 0 \\
\hline 60 & 3600 & 3444 & 0 \\
\hline 70 & 4200 & 4481 & 0 \\
\hline 80 & 4800 & 3566 & 2.9 \\
\hline 90 & 5400 & 2811 & 33.8 \\
\hline 100 & 6000 & 1820 & 47.4 \\
\hline
\end{tabular}

Hasil tes dari API dapat kita simpulkan bahwa API bisa diakses maksimal 70 client bersamaan atau maksimal 4200 request perdetik. Karena di 80 client atau diatas 4200 request perdetik error mencapai $44.5 \%$ dan terus bertambah. Selanjutnya adalah tes untuk website, dari tes untuk website didapat hasil seperti di Tabel IV.

Untuk website dapat kita simpulkan bahwa website bisa diakses kurang dari 80 user dalam waktu persamaan atau maksimal 4800 request tiap detiknya. Karena diatas 80 user atau diatas 4800 request perdetik website sudah mulai tidak mampu.

\section{KESIMPULAN DAN SARAN}

Kesimpulan yang dapat diambil dari pengembangan API dan website Marketspot disini adalah

1. Marketspot merupakan sebuah aplikasi Geo Social Commerce yang eklusif di mobile phone untuk membantu penjual bertemu dengan customer disekelilingnya dengan menampilkan customer yang membutuhkan di sebuah peta, dapat langsung berinteraksi dan begitu sebaliknya. Dalam solusi ini kami menggabungkan unsur social dan e-commerce yang berbasis GIS.

2. API Marketspot dalam penelitian ini adalah REST API dengan output benbentuk JSON. Setiap fitur di API telah diakses dengan aplikasi Marketspot di android dan berjalan baik.

3. Fitur-fitur pada website marketspot sudah berfungsi dengan baik sesuai dengan rancangan.

4. Hasil Pengujian yang telah dilakukan membuktikan bahwa kinerja API dan Web cukup seimbang dan sesuai harapan.

Berdasarkan penelitian yang telah dilakukan adapun hal yang perlu dikembangkan adalah hardware pendukung, dalam hal ini adalah server. Server yang dipakai dalam penilitian ini termasuk server dengan spesifikasi rendah. Aplikasi ini berhasil di optimasi untuk berjalan deserver dengan spesifikasi rendah. Untuk mendapatkan hasil yang lebih optimal dan user yang jauh lebih banyak bisa dideploy di server yang memiliki spesifikasi lebih tinggi. Selain itu fitur di Marketspot juga masih bisa dikembangkan, terutama fitur gamification dan reporting.

\section{DAFTAR PUSTAKA}

[1] J. R. M. W. F. O. John-Luc Bakker, "Rapid Development and Delivery of Converged Services Using APIs," Bell Labs Technical Journal, pp. 1213, 2000.

[2] S. Spencer, J. Harding and J. Sheahan, Social eCommerce, Sebastopol: O'Reilly Media, Inc, 2014.

[3] L. Indvik, "The 7 Species of Social Commerce," 10 $122014 . \quad$ [Online]. Available: http://mashable.com/2013/05/10/social-commercedefinition/. 